\title{
Female Masculinity in Radclyffe Hall's Novel The Well of Loneliness
}

\author{
Shankar Subedi*
}

\begin{abstract}
This paper aims to analyze Radclyffe Hall's novel The Well of Loneliness from the perspective of female masculinity. For that purpose, it uses the concept of female masculinity developed by Judith Halberstam. Seen from the angle of female masculinity forwarded by Habersham, the present paper comes to the conclusion that masculinity falls into crisis as we compare it to how it was defined and understood traditionally. Most of the female characters in the novel show boldness, strength and ability to face and tackle different situations filled with danger and hopelessness. A young woman named Stephen Gordon pursues her passions and embarks on her own subjective world. Her activities and choices are anomalous to the established mores concerning the role and position of women. This is what goes against the conventional paradigm of gender and supports the idea of subversive female masculinity.
\end{abstract}

Keywords: female masculinity, heterosexual normatively, inversion, gender roles, paradigm shift

\section{Introduction}

This paper intends to analyse the issue of female masculinity in relation to Hall's The Well of Loneliness from Halberstam's notion of female masculinity. The issue of female masculinity is distinctly present in the novel. Female masculinity is not a byproduct of male masculinity. It is a specific gender with its own cultural history. Those who have female masculinity are not simply manly trying to copy heterosexual males. They follow and develop their own unique gender identity. Examining female masculinity along with normative masculinity sheds light on the important ways that fictional characters can contribute to showing how masculinity is a construct.

Stephen Gordon shows appreciable features of masculinity. She follows her fiancé to the war-hit area and finally has no option other than confronting the vicissitudes of life. She comes to love Mary Llewellyn, whom she meets while serving as an ambulance driver in the First World War. Their happiness at the same time is diluted by social rejection and a kind of loneliness. Stephen starts dressing up as a male. She falls in love with Angela. Angela is the American wife of one of her neighbors.

*Mr. Subedi has done Mphil in English and is pursuing PhD from Tribhuvan University. Currently he has been working as Lecturer in English at the Central Department of English, Tribhuvan University, Kirtipur, Nepal. 
Angela finds Stephen as a remedy against boredom, permitting her some friendly kisses. Then she finds that Angela has an affair with a man. Afraid that she will be exposed, Angela shows a letter from Stephen to her husband, who sends a copy to Stephen's mother to inform her of her daughter's socially unacceptable sexual orientation.

Stephen doesn't like going to the parties. She hates trivial discussions and dressing up in colorful clothes. She would rather like to dress as a gentleman. She has no interest in what women talk about and men also rarely talk about her. She meets young man, Martin Hall who shows keen interest in her talk. Over the course of one winter, Stephen and Martin become very close. They spend nearly every day together exploring many beautiful natural sites. But the relation does not develop along the lines of traditional man-woman relation because of Stephen's sexual choices. Lady Anna, Stephen's mother allows herself to hope that this relationship will turn into marriage and creates a normal life for her only child. However, the moment Martin declares his love for Stephen, she pushes him away. This is because Stephen is a woman and she doesn't want her relationship with a male to evolve into marriage. This goes against the traditional understanding about heterosexual normatively.

Lady Anna chides her daughter Stephen for using the word love and her willfulness as well as her boldness to face reality pertaining to war and her unpalatable difference from the traditional kind of femininity are some of the main ingredients of her masculinity. Mary Llewellyn assumes that the war belongs to what we call the man's domain. Military uniform signifies her sense of masculinity. Her view of war and masculinity is taken seriously by Stephen. But she longs to experience the consequences of battle closely standing by those who take part in the fight actively.

A writer friend of hers advises Stephen that she needs to gather more experience to refine her writing. Departure from fixed roles and dislike for heterosexual norms force Stephen to pay expensively for it. Stephen joins the French Army Ambulance Corps. She brings soldiers from the war hit areas to hospitals in the rural areas.

In course of time, Stephen becomes intimate with fellow drivers, a young girl called Mary Llewellyn is a special one. After the war is over, they go vacationing as a remedy for stress created by the war. Stephen does not really want to be attached to Mary because she has a fear that her relation with Marry would bring a taint with it in society. However, Mary convinces Stephen that she understands her and is strong enough to handle their relation.

Some traits associated with heterosexual masculinity have negative meanings. A noted critic of Hall, A.K.M. Aminur Rashid finds the decline of heterosexual norms and remarks about "Violent social upheaval ... showing off masculinity, drinking alcohol and womanizing. In The Well of Loneliness Mary tends to see the world through a military lens. She enjoys the male camaraderie of war" (Hall, 1981, p. 29). The feelings 
of despair and disenchantment brought about by war fills the entire account of Hall. Although she is mainly reputed for The Well of Loneliness, her other works engage with the lives of various members of the middle class. Her actions, and her desire to cross the boundary forms an important part of her manliness. She is very different, compared to the destiny of many women in England during the Victorian period.

Her courage to work in a volatile area affected by war is extraordinary. The social assumption to be confined in a narrow domestic role where patriarchy controls and maintains its rule is directly rejected by her. Mary's will to survive and work in the war-hit area is indicative of how masculinity fuels her activities. Usually it is the males who enlist as soldiers and show bravery and strength in the battlefield. Valor and the tendency to take risk were conventionally regarded as alien to women. They were supposed to belong to the periphery of domestic life and it was understood to be their only destiny. If we look at the history of war, we come to know that there were almost no woman warriors. Even when there were some, the number was very negligible. Stephen and her friends' decision to take part in the war is a supreme example of how women can display traits of masculinity and challenge conventional notions of gender roles.

\section{Theory and Textual Analysis}

The article uses the theoretical notion of female masculinity forwarded by Judith Halberstam. Halberstam puts forward the new concept of alternative masculinity. For Halberstam, female masculinity is "about women who feel themselves to be more masculine than feminine" (Halberstam, 2005, p. 21). In other words, female masculinity can be described as persons born as females feeling more at home behaving as masculine. Cora Kaplan's view, more focused on the relation between language and gender, claims "Our individual speech does not... free us in any simple way from the ideological constraints of our culture since it is through that forms that articulate those constraints that we speak in the first place" (Kaplan, 2005, p. 10). In this sense, female masculinity has to be regarded as a specific gender in its own right. There is no need to compare it with other models of masculinity because it stands on its own and enjoys an independent existence.

Halberstam remarks that the analysis of the contemporary idea of masculinity cannot be understood without paying equal heed to the kind of masculinity naturally present in women. Halberstam, in her book Female Masculinity, remarks "Female masculinity is not merely a perverse supplement to dominant configurations of gender, but masculinity itself cannot be fully understood unless female masculinity is taken into account. Female masculinity has played a crucial but unrecognized role in the emergence of contemporary formations of the masculine" (Halberstam, 2005, p. 43). 
Masculinity, known as a state of being, suggests ownership that other words related to masculinity do not denote.

To refer to this state of existence, one should have masculine traits. But this idea of owning creates problem for men. It may carry the sense that men can have these qualities whereas women cannot even imagine of having these qualities. It sounds like what we understand as masculine traits are the sole properties of men and women cannot make any claim as to the right of having them. Many intellectuals, have inspected masculinity with a major focus only on males. In this connection, Halberstam contends, "If what we call 'dominant masculinity' appears to be a naturalized relation between maleness and power, then it makes little sense to examine men for the contours of that masculinity's social construction" (Halberstam, 2005, p. 2). By examining masculinity of women we broaden our understanding of masculinity and its multifarious functions in the political and cultural situation of the Eighteenth century.

It is understood that a person's biology decides sex and sex decides gender, and gender decides sexuality. To use the word "determine" may not be appropriate as it will remain open to new socio-cultural norms and constraints. In The Well of Loneliness, the notion of female masculinity is presented clearly. Stephen's childhood spent in the company of Violet and Roger serves as a fine example of how certain masculine features are obtained by a woman who is disposed to masculinity. The presence of the opposites may create frustrating situations as the people belonging to two different genders may be compartmentalized within the categories they are considered to belong to. A masculine person is stronger in the sense of being more assertive, confrontational, and competitive. He or she acts in a way that is indicative of autonomous manner in which individuals may perform themselves. The categories created by society are porous and can always be violated by the real people functioning in the actual world.

Whatever is masculine is a social construct and cannot play any decisive role in the determination of gender. Power and discourse play a vital role in constructing it. Whatever is said by the people in power comes to serve as a definition of what is manly and what is womanly. Foucault claims that this is exactly what came into being in the eighteenth century and was carried over into the next. For Foucault, "Discourse transmits and produces power; it reinforces it, but also silence and secrecy are a shelter for power, anchoring its prohibitions; but they also loosen its hold and provide for relatively obscure areas of tolerance" (Foucault, 1998, p. 101). In this way, we cannot undermine the role of discourse in the generation of truth about what is true and false. In this context, the masculine and the feminine are also social constructs and it is always possible for women to perform as masculine females.

Halberstam's Female Masculinity studies the social and political positions of masculine women. She analyses women whom we cannot think to fall into the group of 
the women. "Female masculinity is a way of representing oneself in a manner that challenges the dominant discourse on gender and sexuality, according to which men should be masculine and women should be feminine; it also shows the constructed nature of masculinity S (Halberstam, 2005, p. 1-2). Thus gender role is expressed through the way a person speaks. Halberstam's understanding of the effect of language is in line with Foucault and Butler. She argues that language is "a structure that fixes people and things in place artificially but securely" (Halberstam, 2005, p. 7). In this way, gender is a manner in which people do their roles in different ways in real life. Roger and Violet make fun of traditional gender roles. It is a proof that gender roles are not fixed and what they mean depends on how people perform them.

Thus, Stephen's dislike for Roger and Violet shows that her gender identity does not define itself in terms of binaries. Violet is the cause of the nuisance. At one-point Violet says, "Can't you knit? She would say, looking scornfully at Stephen, I canMother called me a dear little housewife! Roger strutting about in his Etons, and bragging, always bragging because he was a boy" (Hall, 1981, p. 65). This description shows Stephen's loneliness. She does not show any identification with any one of them but has a stance on her own position. Stephen has no envy for Roger but envies his behavior as a man. Stephen also does not imitate Roger and would just like to teach her a lesson. Stephen's gender seems to be unique because she looks like a boy and wants to take part in the battle which goes against the traditional understanding of what men and women usually go for.

Stephen's disillusionment with the beauty and boldness affects her mother because, as the narrator remarks, "But Anna, looking gravely at her daughter, noting the plentiful auburn hair, the brave hazel eyes that were so like her father's, as indeed were the child's whole expression and bearing, would be filled with a sudden antagonism that came very near to anger" (Hall, 1981, p. 6). It is obvious that Stephen has always felt lonely from early on. The only child of her parents, she is grown up as the son and is close to her father in terms of activities that denote masculinity. This is the reason why her mother finds it difficult to love her child and it serves as the cause of her detachment from the other people in the community and the society as a whole. She is treated as the odd person out and stands aloof from the other people in the neighborhood.

Female masculinity does not simply mean to attain to the status of men, it also means to assert the kind of feelings and emotions that women have and an attempt to give an expression to them. Manhood or masculinity, in turn, is a 'continual dynamic process' through which men seize public authority (Halberstam, 2005, p. 49). Female condition is not only the result of what men have done but also the consequence of what women have been willing to endure. Nevertheless, Halberstam argues against such a 
monolithic view of female masculinity: "after all, it can also function as a form of social rebellion or a 'sign of sexual alterity" (Halberstam, 2005, p. 9).

Angela in a way betrays Stephen in her relation with the girl. They spent a lot of time together talking about friendship and the kind of gifts they could exchange. Angela mentions this to her hubby in some of the casual conversations they have. Stephen's penchant for doing something unconventional and radical is indicated by, "How she hated soft dresses and sashes, and ribbons, and small coral beads, and openwork stockings! Her legs felt so free and comfortable in breeches" (Hall, 1981, p. 12).

As she grows up she does not even know that the things she does can have a name of their own. Stephen's father understands her but he has difficulty explaining it to her. When Stephen's father dies she wonders what is going to happen to her from her risky love affair. This allows her mother to know her and it brings a kind of closeness in the relation between the mother and the daughter. Female Masculinity is not an inclusive book due to its vague and inadequate explanation of some key ideas. Some of the key ideas are left unexplained and when they have an explanation it really falls short of the kind of length that it justly requires. Stephen comes to know that there are others like her and masculinity is something that everyone can lay a claim to if he or she has the necessary traits needed to qualify as one. She is too willing to take a lover who she thinks is sure to provide her the kind of affection that she has long been after. She is aware of the reasons why the society she lives in is finding it difficult to accept her. This is the kind of society that only takes from an individual but refuses to give to them what they are worthy of. Stephen Gordon has her first crush at seven. It does not occur to Stephen that there is "anything unusual about having a crush on a woman until she catches the object of her affection kissing a man. Stephen turns to her father for understanding" (Hall, 1981, p. 76). Sir Philip turns to the popular psychological writers of the time to learn what kind of socially challenging future lies ahead for his unusual daughter.

Halberstam asks us to look at familiar texts and problems in new ways and leaves space for new scholarship to expand the critical thought. In her book Halberstam makes it clear that the masculinity of women can be studied without referring to the masculinity of males. Halberstam argues that female masculinity is not merely a supplement to influential definitions of gender. To understand female masculinity, we have to take into account the idea of masculinity itself. In this regard, Halberstam postulates that "Female masculinity has played a crucial but unrecognized role... cultural intolerance towards the gender ambiguity that the masculine woman represents" (Halberstam, 2005, p. 78).

In the novel Stephen meets a young man named Martin Hallam who is interested in what she has to say. During the period of one winter, Stephen and Martin become 
very close. They spend nearly every day together exploring nature. Lady Anna hopes that this relationship will turn into marriage. She expects that it creates a normal life for her only child. She wants her child to have a normal life and it is only possible when her child lives life the way a normal individual does. After Martin leaves, Sir Philip grows stronger in his plans for Stephen. The following confession on the part of Sir Philip throws light on the peculiar power of Stephen to face reality in an unconventional way, "For this reason, Stephen chooses to remain at Morton rather than attend school at Oxford. Sometime after her father's death, Stephen meets Angela Crosby, an actress from New York. Stephen falls head over heels for Angela and it appears that her love is returned" (Hall, 1981, p. 66).

Unable to develop a stable psychic state, Stephen is divided between nostalgia for a womanliness and a strong sense of self hood. The husband sends this letter to Lady Anna, which creates tension in the relation between the father and the daughter. It shows that every culture has its constraints in the form of cultural values and assumptions and these rules of expectations play a decisive role in the formation of identity of the members of that particular society. The external world and the language we are provided from childhood have enormous impacts on our understanding of the world as well as our self-awareness. Addressing this side of impact of gender normativity, Toril Moi contends, "Moreover, it is easier to identify which factors have an important role in the formation of female identity than which factors actually comprise that identity. Stating that identity is a sum of particular constituents would mean claiming that identity itself is fixed" (Moi, 2004, p. 14). The examination of female identity is a both a risky and a thrilling task in which one can reach certain points of determinacy but new doors of possibilities open up and we may have to ask new questions and explore the new issues in a new light.

The most common understanding of what a woman is has to do with the fact that she is an individual with a female body. This assumption highlights the anatomical and physical differences between men and women and points to the importance of the body in a social context. Anatomy is one thing but femininity or masculinity implies that the roles individuals play in society have a greater role to play in deciding the gender of people and the borders between different genders are always porous and are always open to change and challenge.

Defining identity in terms of the body has certain drawbacks and scholars have always tried to move the emphasis from the study of the body to sociocultural forces that largely contribute to shaping the gender identity of an individual. Stephen is always wary of the difficulties that her relation with Mary would create. With its own values and expectations, the society would see the relation as a problem and something unconventional. The first few months they are together are the happiest Stephen has 
ever experienced. Stephen returns to her writing. She leaves Mary without an occupation to fill her days. When Stephen notices Mary's unhappiness, she takes her to parties at the home of Valerie Seymour, a lesbian living in Paris. Through Valerie, Mary and Stephen meet many people like themselves.

Lady Anna becomes excited, imagining Stephen marrying Martin and living a normal life. However, it all comes to a pause when Martin declares his love to Stephen. Stephen becomes terrified and goes away from him not considering the ties of friendship that had developed over the years. Deeply hurt by the rejection, Martin leaves London soon after that. Stephen, traumatized by the death of her father, "decides to remain at Morton rather than go to Oxford. Puddle wants to help Stephen, to explain why her father so desperately wanted her to go to Oxford, but she cannot speak the truth out of fear of Lady Anna's reaction" (Hall, 1981, p. 141). Stephen refuses to concentrate on her studies. The only comfort Stephen can find is in the horses. However, an attempt to hunt without her father fails miserably and Stephen cannot do it again.

In terms of heterosexual assumptions masculinity and femininity are in opposition to one another. This binary view of gender stems from "the idea that there are only two sexes: male and female. In fact, it is impossible for a concept to escape discourse, as even extra-discourse, that which is outside discourse is produced by discourse" (Hall, 1981, p.11). This concept echoes Foucault's idea of power, in which resistance can never escape the power with which it is in opposition. There is a link between power and discourse, but it is tentative: all at once, discourse can be "an instrument and an effect of power" (Foucault, 1998, p. 101). Foucault states: "Discourse transmits and produces power; it reinforces it, but also undermines and exposes it, renders it fragile and makes it possible to thwart it" (Foucault, 1998, p. 101).

There is also a link between power, language, and discourse: "power's hold of sex is maintained through language, or rather through the act of discourse that creates, from the very fact that it is articulated, a rule of law" (Foucault, 1998, p. 83). Language is a means of producing discourse so that both speech and writing can be considered as examples of discursive practices. Every discourse is based on the principle of exclusion as it keeps outside itself whatever fails to abide by the formations that it has brought into existence. Yet, the same subjects are unable to evade the discourse. In the case of gender, those who present a "non-viable gender has their very humanity scrutinized and may be denied cultural intelligibility" (Butler, 1990, p. 15). This sort of expulsion has also been viewed as "a strategy of domination" (Butler, 1990, p. 144), which can be seen in the case of women, minorities, and gay rights.

Stephen goes scratching for sand lances, a species of small fish. While on their way to a beach, where they plan to fish, "Stephen follows the others up the road. She feels a keen identification with the night and is reluctant to leave it. All the wildness of 
her spirit night liberated with a touch" (Hall, 1981, p. 312). She could only "wait at the window, desolate with lost adventure, desolate with a boyishness that might never put to sea, denied the secrets of the wind and dawn a sailor has by heart" (Hall, 1981, p.377). The wildness of the hour took Stephen's heart in its strong grasp. Stephen's love for what is risky and adventurous defines her as an individual who is all the time on the lookout for something new and unconventional for woman. Her behavior and activities show her as a masculine female.

\section{Conclusion}

To sum up, Stephen represents a masculine of a unique type. Her masculinity stands in its own right and cannot be treated as a byproduct of the masculinity of males. It emanates from an individual female's subversive acts, different nonconformist choices and anomalous patterns of thinking. Stephen stares at the mainland, rigid with rebellion. This identification with the night can be considered to symbolize Stephen's falling outside the limits of hetero-normative society. Her very name is suggestive of what the author wants her to represent. She does not like to enter into heterosexual relations with males and instead pairs with other females and behaves as a masculine male herself. She opts for dressing up as a boy and deliberately chooses to work in the military which we can understand as an inversion of traditional expectations about gender roles.

\section{References}

Rashid, A.K.M. Aminur (2001). Radclyffe Hall's loneliness. The Journal of Lesbian Studies, vol.3, no.1, pp. 151-158.

Butler, J. (1990). Gender trouble: Feminism and the subversion of identity. New York, Routledge.

Foucault, M. (1998). The history of sexuality. New York: Pantheon Books. Halberstam, J. (2005) . Female masculinity. New York: Duke University Press. Hall, R. (1981). The well of loneliness. London: Jonathan Cape.

Kaplan, C. (2005). Subversive femininity. New York: Vivian Publication.

Toril, M. (2004). Fluidity and failure: Spectrum of masculinity. London: Edinburgh, Cannon Gate. 